\title{
Petrology and U-Pb geochronology of buried Avalonian plutonic rocks on southeastern Cape Cod
}

\author{
G.W. Leo ${ }^{1}$, J.K. Mortensen ${ }^{2}$, B. Barreiro ${ }^{3 * *}$, and J.D. Phillips ${ }^{4}$ \\ ${ }^{1}$ United States Geological Survey, 928 National Center, Reston, Virginia 22092, U.S.A. \\ ${ }^{2}$ Geological Survey of Canada, 601 Booth Street, Ottawa, Ontario K1A 0E8, Canada \\ ${ }^{3}$ Department of Earth Sciences, Dartmouth College, Hanover, New Hampshire 03755, U.S.A. \\ ${ }^{4}$ United States Geological Survey, Denver Federal Center MS 964, Denver, Colorado 80225, U.S.A.
}

\author{
Date Received February 8, 1993 \\ Date Accepted June 30, 1993
}

\begin{abstract}
Plutonic rocks have been intersected by two separate drill holes on southeastern Cape Cod. Hole CC2 is located at Chatham Harbor about $7 \mathrm{~km}$ south of the Nauset anomaly, an east-northeast-trending magnetic lineament that was considered to separate the distinct plutonic zones of Avalon terrane. This drill hole intersected weakly foliated, fairly homogeneous biotite granite. Zircons from this granite give a $\mathrm{U}-\mathrm{Pb}$ age of $584+9 /-8 \mathrm{Ma}$. Hole $\mathrm{CCl}$ is located near North Eastham, about $12 \mathrm{~km}$ north of the Nauset anomaly. The drill core intersected foliated, sheared, biotite granodiorite and biotite-homblende-clinopyroxene-quartz gabbro, metamorphosed to greenschist facies. The deformed and altered state of these rocks, as well as their geochemistry, suggest that their origin and possibly their ages are distinct from the granite in hole CC2. No datable zircons were obtained from rocks in CC1.

The age of $584 \mathrm{Ma}$ for the CC2 granite sample is within the range of published ages for plutonic rocks of the Avalon terrane and confirms the suggestion of Hutchinson et al. (1988) that the southern plutonic zone is a part of the Avalon terrane. The data also indicate that the Nauset anomaly is not the Avalon-Meguma terrane boundary in this area.
\end{abstract}

Des roches plutoniques ont été recoupées par deux forages distincts dans le sud-est de Cape Cod. Le forage CC2 est situé à Chatam Harbor à environ $7 \mathrm{~km}$ au sud de l'anomalie de Nauset, un linéament magnétique d'orientation estnord-est qui était considéré comme séparant les zones plutoniques distinctes du terrain d'Avalon. Ce forage a recoupé un granite à biotite faiblement folié et très homogène. Des zircons de ce granite donnent un âge U-Pb de 584 $+9 /-8$ Ma. Le forage $\mathrm{CC} 1$ est situé près de North Eastham, à environ $12 \mathrm{~km}$ au nord de l'anomalie de Nauset. Le sondage a recoupé de la granodiorite à biotite et du gabbro à biotite-homblende-clinopyroxène-quartz foliés et cisaillés, métamorphisés au faciès des schistes verts. La nature déformée et altérée de ces roches, ainsi que leur géochimie, suggère que leur origine et possiblement leur âge soient distinct du granite du forage CC2. Aucun zircon datable ne fut obtenu des roches dans le CC1.

L'âge de 584 Ma pour l'échantillon de granite CC2 tombe dans l'intervalle des âges publiés pour les roches plutoniques du terrain d'Avalon et confirme la suggestion de Hutchinson et al. (1988) que la zone plutonique méridionale est une partie du terrain d'Avalon. Les données indiquent aussi que l'anomalie de Nauset n'est pas la frontière des terrains d'Avalon et de Méguma dans cette région.

[Traduit par la rédaction]

\section{INTRODUCTION}

In the fall of 1987, the United States Geological Survey (USGS), in collaboration with the Massachusetts Department of Environmental Management, Division of Water Resources, drilled two wells through nonlithified Pleistocene sediments into bedrock at North Eastham and Chatham,

*Present address: Department of Geological Sciences, University of British Columbia, Vancouver, British Columbia, V6T 1Z1, Canada

**Present address: Isotope Sciences Laboratory, c/o British Geological Survey, Keyworth, Nottingham, United Kingdom NG1 $25 G$
Cape Cod (Figs. 1, 2) (Leo and Phillips, 1989; Leo et al., 1991). The purpose of the drilling was four-fold: (1) to collect a complete lithostratigraphic record of Quaternary and possibly Coastal Plain sediments; (2) to delineate potential aquifer zones that might contribute to public supply wells; (3) to assess the rock types and geochemistry of the bedrock; and (4) to attempt to obtain U-Pb zircon ages on the cores. The present paper deals with the last two objectives. The following descriptions of the geology of central Cape Cod are based largely on Wones and Goldsmith (1991). We discuss the petrological characteristics of igneous rocks intersected by the two drill holes, and report a U$\mathrm{Pb}$ zircon age for a sample of granite from hole $\mathrm{CC} 2$. 


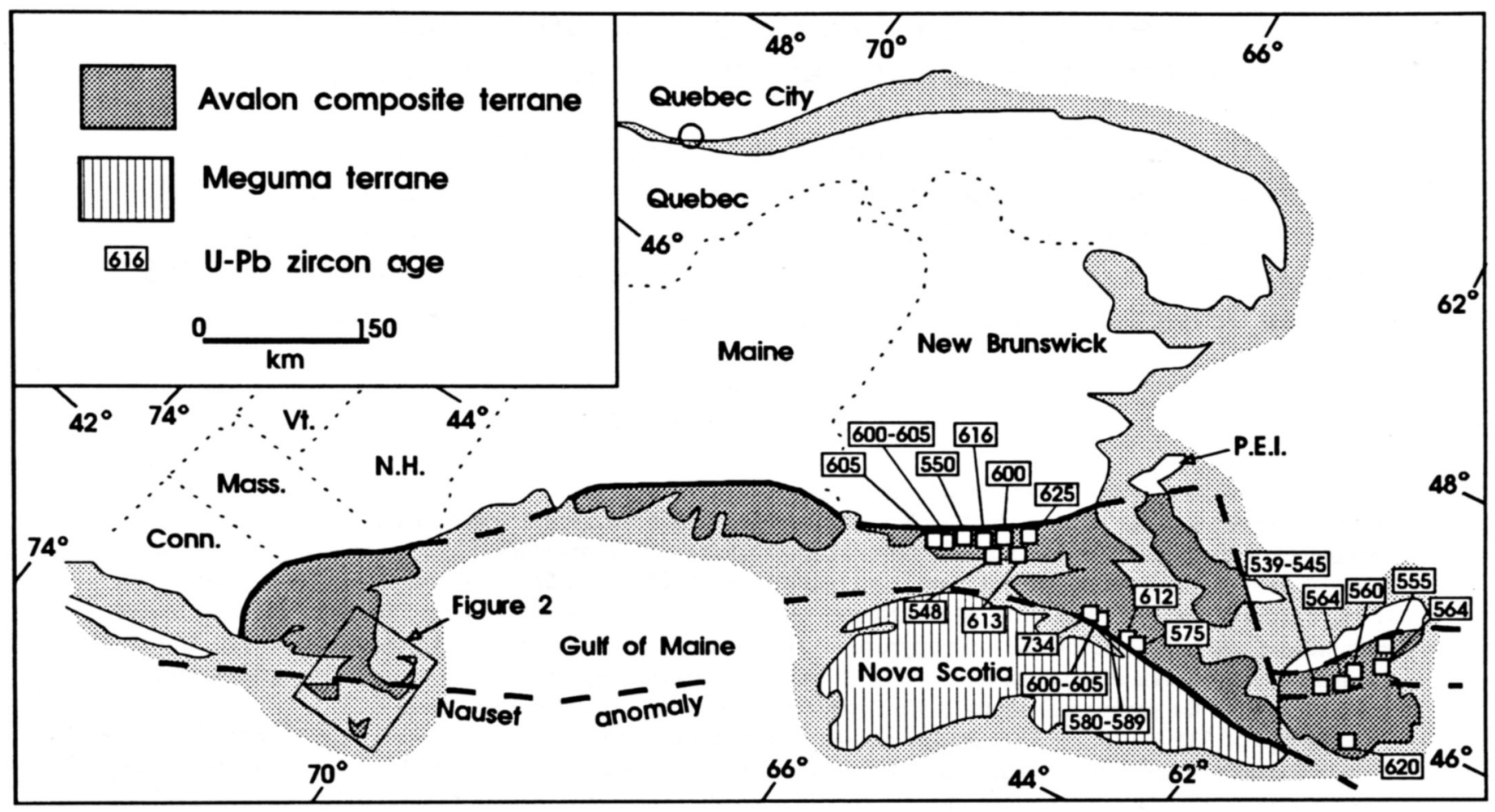

Fig. 1. Map of the northern Appalachians, showing known and inferred extent of the Avalon composite terrane (modified from Hutchinson et al., 1988; Barr et al., 1990; Keppie et al., 1990). U-Pb zircon ages for Late Proterozoic and Cambrian volcanic and plutonic rocks in the Avalon terrane from Bevier and Barr (1989), Bevier et al. (1990), Barr et al. (1990), Dallmeyer et al. (1990), Sangster et al. (1990), and Doig et al. (1991).

\section{Geology of Cape Cod}

Cape Cod is covered entirely by Pleistocene glacial deposits, and the geology of underlying bedrock is known only from several deep drill holes. The westernmost outcrops near the Cape are exposed along a line running approximately from Rocky Point to Marion, Massachusetts (Fig. 2). The concealed crystalline bedrock of the Cape was designated as undivided granite, gneiss, and schist by Zen et al. (1983) and Wones and Goldsmith (1991, p. I27). KAr mineral ages have been reported (Zartman and Marvin, 1991) from granitoid rocks in several drill cores in the Harwick-Brewster area (Fig. 2). One such core, north of Brewster, gave K-Ar (biotite and hornblende) ages in the range of 566 to $348 \mathrm{Ma}$ (Zartman and Marvin, 1991). These were considered to be minimum ages, and a Proterozoic $Z$ (Avalonian) age was assumed for at least part of the basement under Cape Cod. Few petrologic or geochemical data are available for these scattered drill cores, and the significance of the isotopic ages obtained from them is uncertain.

\section{New Drill Intersections of Crystalline Basement}

Hole $\mathrm{CCl}$ is located in a gravel pit on the northern outskirts of North Eastham, $300 \mathrm{~m}$ east of US Route 6, and north of Oak Leaf Road, about $20 \mathrm{~km}$ north from the center of Chatham village. Hole CC2 is located on Champlain Road at its intersection with State Harbor Road about 2 km south-southwest of the center of Chatham village (Fig. 2).

The northern hole (CC1) was drilled to a depth of 185 $\mathrm{m}$ and penetrated $35 \mathrm{~m}$ into crystalline basement. The southern hole (CC2) at Chatham Harbor was drilled to a depth of $123 \mathrm{~m}$ and penetrated $11 \mathrm{~m}$ into basement. Compositionally, the $\mathrm{CCl}$ core ranges from gabbro to granodiorite or monzogranite (analyses 1-3, Tables 1, 2; Figs. 3,4). The texture is mostly medium-grained and equigranular with a more or less well-preserved hypidiomorphic granular aspect, but locally it is blotchy and uneven with granite dikes and veins crosscutting gabbro (Fig. 3-1). The quartz gabbro (analysis 1, Table 1) contains plagioclase, hornblende, clinopyroxene, biotite, epidote, and about $6 \%$ magnetite. Plagioclase (30\%) shows sharp albite twinning and moderate zoning. Compositions of representative grains determined by flat-stage optical methods yield $\mathrm{An}_{44}$, $A n_{25-40}$, and $A n_{24-31}$. Metamorphic recrystallization is minimal to moderate, indicated by slight to extensive replacement by sericite and epidote. Large grains of green hornblende poikilitically enclose green-gray, non-pleochroic clinopyroxene. Olive-brown biotite and blebby, strongly strained quartz each constitute $2 \%$ of the quartz gabbro by volume. Titanite is an uncommon accessory. The quartz gabbro sample is mildly tectonized and locally intruded by 


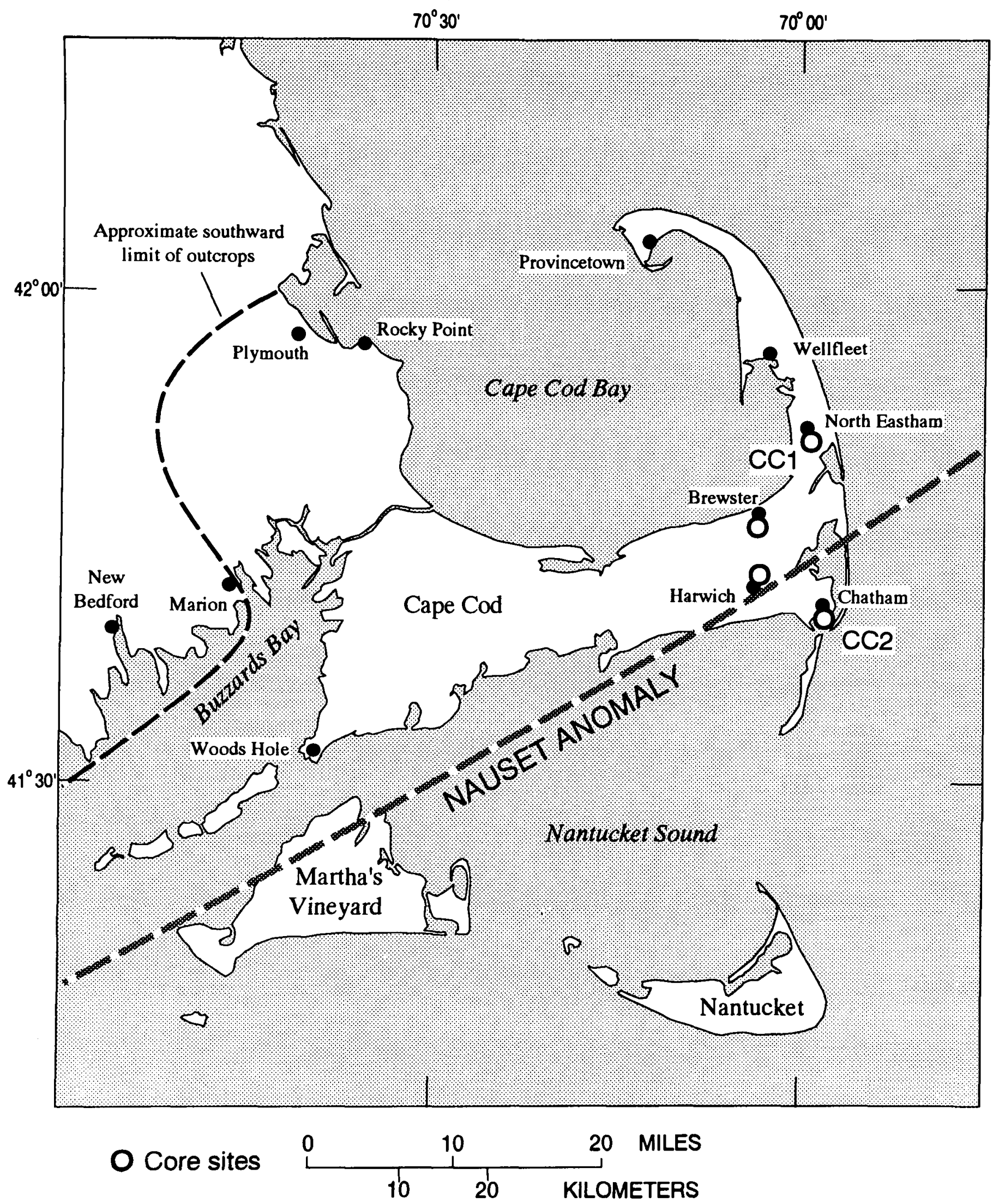

Fig. 2. Location map of Cape Cod (modified from Wones and Goldsmith, 1991, fig. 17), showing selected drill hole sites in crystalline basement rocks, some with K-Ar age determinations. Filled circles = towns; open circles = drill hole localities in the Harwich-Brewster area, as well as the North Eastham (CC1) and Chatham Harbor (CC2) localities. 
Table 1. Modal analyses ${ }^{1}$ of drill core samples, southeastern Cape Cod, Massachusetts.

Core CC1, North Eastham, MA

Core CC2, Chatham Harbor, MA

\begin{tabular}{|c|c|c|c|c|c|c|c|c|}
\hline $\begin{array}{l}\text { Sample No. } \\
\text { Analysis No. }\end{array}$ & $\begin{array}{c}\mathrm{CC} 1-151 \\
1\end{array}$ & $\begin{array}{c}\mathrm{CC} 1-163 \\
2\end{array}$ & $\begin{array}{c}\mathrm{CC} 1-175 \\
3\end{array}$ & $\mathrm{CC} 1-160$ & CC1-185 & CC2-125 & CC2-128 & $\begin{array}{c}\mathrm{CC} 2-123 \\
4\end{array}$ \\
\hline Analysis Symbol & 0 & 0 & 0 & & & & & 口 \\
\hline Quartz & 10.2 & 19.4 & 21.7 & 25.9 & 9.0 & 30.9 & 40.7 & 25.9 \\
\hline Plagioclase & 51.3 & 48.7 & 45.6 & 37.4 & 36.3 & 26.7 & 30.8 & 29.1 \\
\hline K-feldspar & - & 8.2 & 18.7 & 29.2 & - & 37.4 & 25.4 & 42.0 \\
\hline Biotite & 11.9 & 15.2 & 7.6 & 4.5 & - & 2.9 & 2.2 & 2.3 \\
\hline Homblende & 9.4 & 3.5 & 1.0 & 1.0 & 39.6 & - & - & - \\
\hline Clinopyroxene & 6.7 & $t$ & - & - & - & - & - & - \\
\hline Magnetite & 5.8 & 1.8 & 0.3 & 0.9 & 4.6 & 1.8 & 0.6 & 0.6 \\
\hline Apatite & 1.2 & 0.6 & tr & tr & 0.2 & tr & tr & tr \\
\hline Titanite & tr & 1.3 & 0.4 & 0.6 & 0.2 & tr & 0.2 & 0.3 \\
\hline Miscellaneous $^{2}$ & $3.1^{*}$ & $1.1^{*}$ & $4.4^{* *}$ & $0.3^{* *}$ & $9.6^{* *}$ & - & $\mathrm{tr}^{* * * *}$ & $0.1^{* * *}$ \\
\hline Total & 99.6 & 99.8 & 99.7 & 99.8 & 99.5 & 99.7 & 99.9 & 100.3 \\
\hline
\end{tabular}

${ }^{1}$ Modal values normalized to quartz+plagioclase $+K$-feldspar. Three-digit numbers in suffix of sample numbers indicate depths of core samples in meters. O and $\square$ indicate chemically analysed samples of cores CC1 and CC2, respectively (see Table 2 and Figure 4).

$2_{\mathrm{tr}}=$ trace; $--=$ absent; $*=$ actinolite, epidote, chlorite, and saussurite, undivided; $* *=$ mostly garnet; $* * *=$ garnet.

associated granitic rocks that may have differentiated from gabbro. Available data suggest a similarity with the Dedham Granite to the west (Wones and Goldsmith, 1991).

The monzogranite phase of the associated granitic rocks (analyses 2-3, Table 1) consists of plagioclase, quartz, potassium feldspar, green hornblende, olive-brown biotite, and 4 to $0.5 \%$ each of magnetite, titanite and apatite. These rocks reflect lower greenschist facies metamorphism.

The granite at Chatham Harbor (CC2) is fairly homogeneous, fine- to medium-grained pink granite with a weak foliation (Table 1). Microcline and stringy perthite are about equally abundant and together constitute about 25 to $40 \%$ (Fig. 3). The matrix consists of hypidiomorphic granular quartz and subordinate sodic plagioclase. Olive green biotite, magnetite, and titanite constitute 3 to $5 \%$; rounded zircon grains are locally concentrated in biotite.

Textural and compositional comparison between the granite at Chatham Harbor and the granitic phase of the North Eastham cores suggest that the two granites are petrologically distinct.

\section{Geochemistry}

Major- and trace-element analyses and CIPW normative mineralogy for four samples of core are shown in Table 2. The $\mathrm{CCl}$ samples illustrate the compositional variations of this inhomogeneous rock, which ranges from gabbro to monzogranite. Inspection of the core suggests that bulk compositions in hole $\mathrm{CCl}$ are variable from bottom to top, although the composition generally becomes more felsic at shallower depths. The single Chatham Harbor sample was considered large enough to characterize the relatively homogeneous rock, as well as the differences between it and the CCl core.

A linear arrangement of analyzed $\mathrm{CC} 1$ samples (Fig. 4) could be interpreted as differentiation within the $\mathrm{CC} 1$ magma. No comparable trend is evident for $\mathrm{CC} 2$ samples. A clearer distinction between the quartz gabbro and monzogranite phases can be seen in trace element plots. Figure 5 shows Harker plots of relatively stable trace elements or ratios (e.g., $\mathrm{Zr} / \mathrm{Hf}$, Fig. 5-2) which typically yield linear relationships for a given group of related data points. Each plot shows a sublinear relationship through points CC1-151, CC1-163, and CC1-175. However, trace element abundances or ratios corresponding to $\mathrm{CC} 2-123$ (Chatham Harbor) have distinct values. In Figure 5-2, the three most felsic samples (CC1-163, CC1-175 and CC2-123) show comparable linear relationships, but the $\mathrm{Zr} / \mathrm{Hf}$ value of $\mathrm{CCl}-151$ is relatively high. $\mathrm{Cr}$, Th and Ta (Fig. 5-3) have similar abundances for the three $\mathrm{CC} 1$ samples, but the Th content of the granite at Chatham Harbor is significantly higher than in the $\mathrm{CCl}$ cores. The relative trace-element abundances are not distinctive in themselves, but they do suggest that the $\mathrm{CC} 1$ and $\mathrm{CC} 2$ samples represent separate magmas.

Rare-earth element (REE) patterns of the four samples (Fig. 6) all indicate moderate enrichment in light REE and moderate depletion in heavy REE with negligible to moderate Eu anomalies. Total REE abundances, contrary to expectations, are successively higher in the CCl samples in inverse relation to $\mathrm{SiO}_{2}$ content, whereas the granite at Chatham Harbor (CC2-123) has the highest total REE 
Table 2. Chemical analyses ${ }^{1}$ and CIPW normative mineralogy of samples from drill cores from southeastern Cape Cod, Massachusetts.

\begin{tabular}{|c|c|c|c|c|}
\hline & \multicolumn{3}{|c|}{ Core CC1, North Eastham, MA } & \multirow{2}{*}{$\begin{array}{c}\text { Core CC2, } \\
\text { Chatham Harbor, MA } \\
\text { CC2-123 } \\
4 \\
\square\end{array}$} \\
\hline $\begin{array}{l}\text { Sample No. } \\
\text { Analysis No. } \\
\text { Analysis Symbol }\end{array}$ & $\begin{array}{c}C C 1-151 \\
1 \\
0\end{array}$ & $\begin{array}{c}C C 1-163 \\
2 \\
0\end{array}$ & $\begin{array}{c}\mathrm{CC} 1-175 \\
3 \\
0\end{array}$ & \\
\hline \multicolumn{5}{|l|}{ Oxides in percent } \\
\hline $\mathrm{SiO}_{2}$ & 50.40 & 63.50 & 69.70 & 73.40 \\
\hline $\mathrm{TiO}_{2}$ & 1.84 & 0.68 & 0.37 & 0.29 \\
\hline $\mathrm{Al}_{2} \mathrm{O}_{3}$ & 16.20 & 16.00 & 14.20 & 13.40 \\
\hline $\mathrm{Fe}_{2} \mathrm{O}_{3}$ & 5.00 & 2.37 & 1.55 & 0.93 \\
\hline $\mathrm{FeO}$ & 7.20 & 2.80 & 1.40 & 0.84 \\
\hline $\mathrm{MnO}$ & 0.32 & 0.10 & 0.06 & 0.09 \\
\hline $\mathrm{MgO}$ & 4.26 & 1.67 & 0.98 & 0.49 \\
\hline $\mathrm{CaO}$ & 8.31 & 3.76 & 2.25 & 0.91 \\
\hline $\mathrm{Na}_{2} \mathrm{O}$ & 3.30 & 3.36 & 3.26 & 4.10 \\
\hline $\mathrm{K}_{2} \mathrm{O}$ & 1.25 & 4.09 & 4.18 & 4.36 \\
\hline $\mathrm{P}_{2} \mathrm{O}_{5}$ & 0.72 & 0.21 & 0.11 & 0.07 \\
\hline $\mathrm{H}_{2} \mathrm{O}+$ & 0.91 & 0.81 & 0.62 & 0.21 \\
\hline $\mathrm{H}_{2} \mathrm{O}-$ & 0.09 & 0.07 & 0.09 & 0.06 \\
\hline $\mathrm{CO}_{2}$ & 0.23 & 0.08 & 0.11 & 0.11 \\
\hline Total & 100.0 & 99.5 & 98.9 & 99.2 \\
\hline $\mathrm{Ba}$ & 378 & 1790 & 1940 & 451 \\
\hline Th & 5.02 & 5.85 & 5.78 & 20.40 \\
\hline $\mathrm{U}$ & 1.74 & 1.56 & 1.28 & 2.60 \\
\hline $\mathbf{Y}$ & 42.2 & 23.2 & 10.1 & 26.9 \\
\hline $\mathbf{Z}$ & 260 & 261 & 146 & 149 \\
\hline $\mathrm{Hf}$ & 1.53 & 5.68 & 3.8 & 5.78 \\
\hline $\mathrm{Ta}$ & 1.11 & 0.39 & 0.32 & 1.51 \\
\hline Co & 25.10 & 9.09 & 5.51 & 1.39 \\
\hline $\mathrm{Cr}$ & 6.30 & 6.10 & 5.80 & 2.30 \\
\hline Sc & 37.8 & 12.8 & 7.0 & 5.1 \\
\hline $\mathbf{L a}$ & 27.0 & 22.0 & 22.4 & 36.9 \\
\hline $\mathrm{Ce}$ & 60.7 & 40.8 & 37.9 & 68.9 \\
\hline Nd & 32.0 & 20.2 & 13.9 & 27.6 \\
\hline $\mathrm{Sm}$ & 7.58 & 4.25 & 2.51 & 6.07 \\
\hline $\mathrm{Eu}$ & 1.77 & 1.44 & 0.83 & 0.78 \\
\hline $\mathrm{Tb}$ & 1.04 & 0.57 & 0.36 & 1.03 \\
\hline $\mathbf{Y b}$ & 3.10 & 1.61 & 1.04 & 3.37 \\
\hline $\mathrm{Lu}$ & 0.47 & 0.27 & 0.16 & 0.49 \\
\hline \multicolumn{5}{|c|}{ CIPW Normative minerals } \\
\hline$\%$ An & 48 & 37 & 27 & 10 \\
\hline $\mathbf{Q}$ & 4 & 17 & 28 & 30 \\
\hline or & 7 & 24 & 25 & 26 \\
\hline an & 26 & 16 & 10 & 35 \\
\hline c & 0 & 0 & 0 & 0 \\
\hline di & 9 & 1 & 0 & 0 \\
\hline hy & 13 & 6 & 3 & 2 \\
\hline $\mathrm{mt}$ & 7 & 3 & 2 & 1 \\
\hline il & 3 & 1 & 1 & 1 \\
\hline ap & 2 & 0 & 0 & 0 \\
\hline
\end{tabular}

${ }^{1}$ Major elements were determined by XRF, with supplementary determinations of $\mathrm{FeO}, \mathrm{CO}_{2}$, and \pm $\mathrm{H}_{2} \mathrm{O}+$. Analysts, J. Taggart, A. Bartel, and D. Siems. Rb, Sr, Ba, Y, Nb, and $\mathrm{Zr}$ were determined by energy-dispersive XRF; analyst, J.R. Evans. The remaining trace elements including REE were done by INAA, long count; analyst, J.S. Mee. 


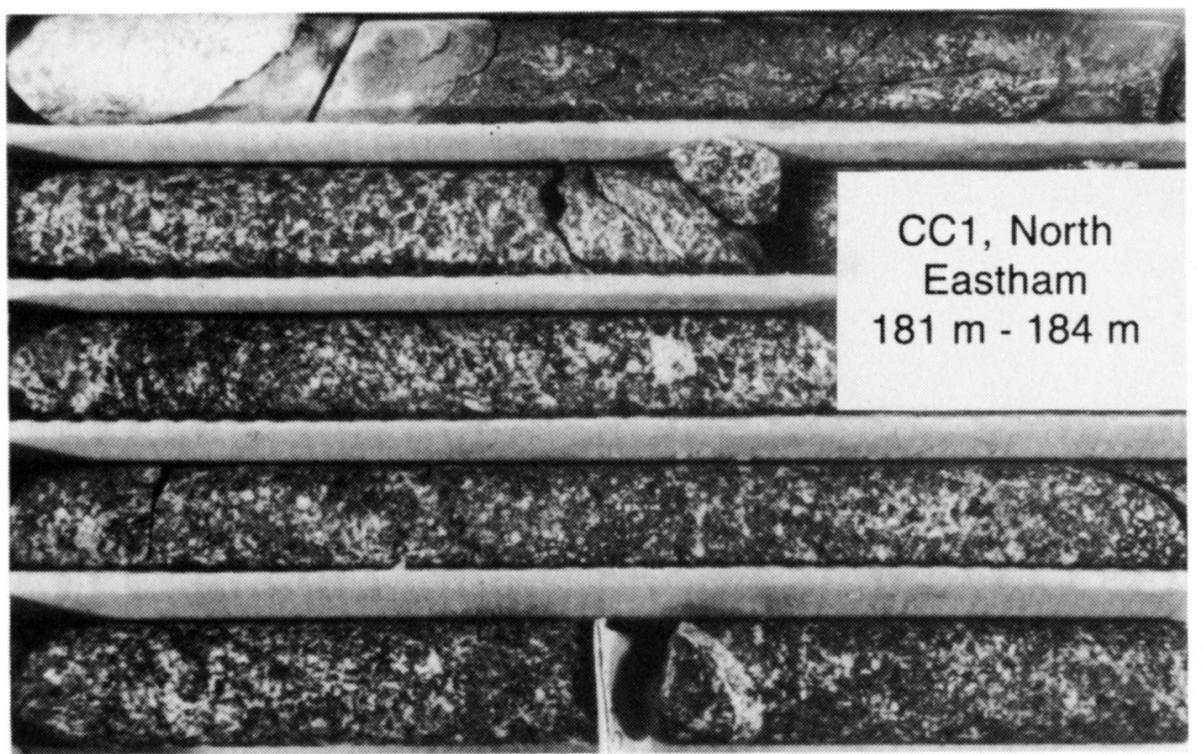

Fig. 3-1

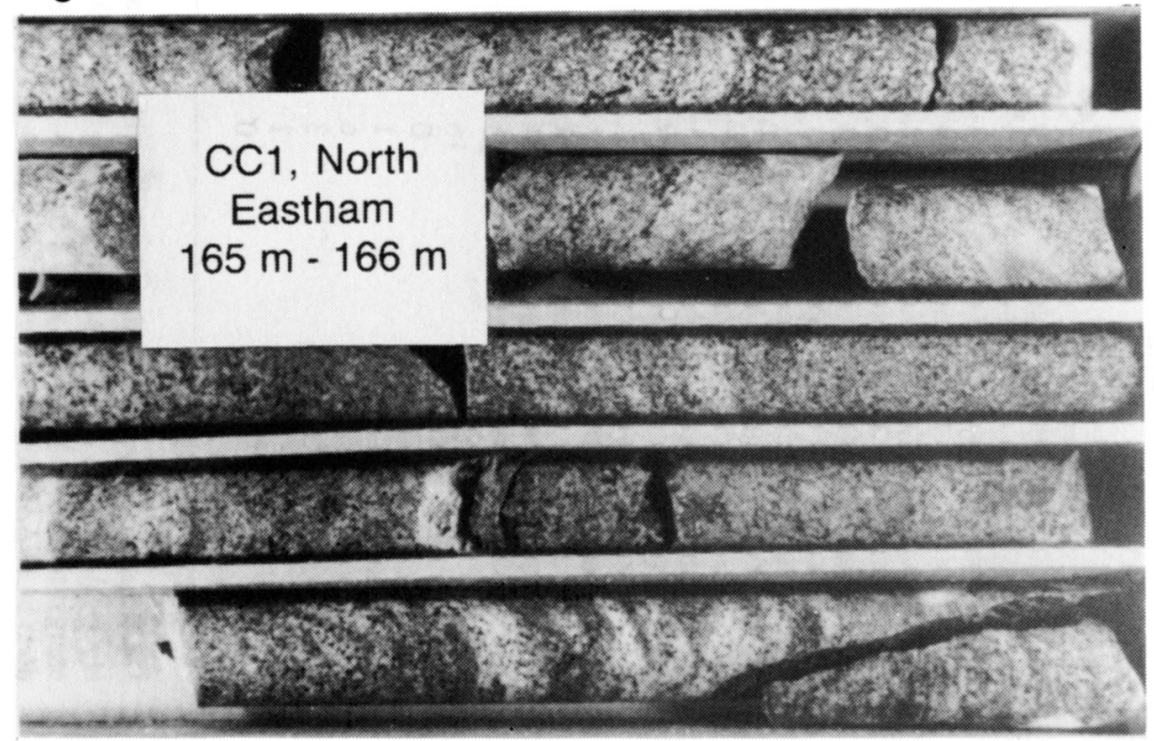

Fig.3-2

Fig. 3. Selected drill cores from boreholes CC1 (North Eastham) and CC2 (Chatham Harbor). (3-1) Quartz gabbro approximates analysis 1, Table 2. Note felsic dike, and blotchy texture related to smaller cross-cutting granitoid veins and dikes. (3-2) Relatively homogeneous quartz diorite-granodiorite-monzogranite corresponding to analysis 2 , Table 2 . (3-3) Homogeneous, more felsic granitoid, approximately granodiorite (analysis 3, Table 1). (3-4) Granite at Chatham Harbor, homogeneous, porphyritic, slightly foliated granite (analysis 4, Table 2).
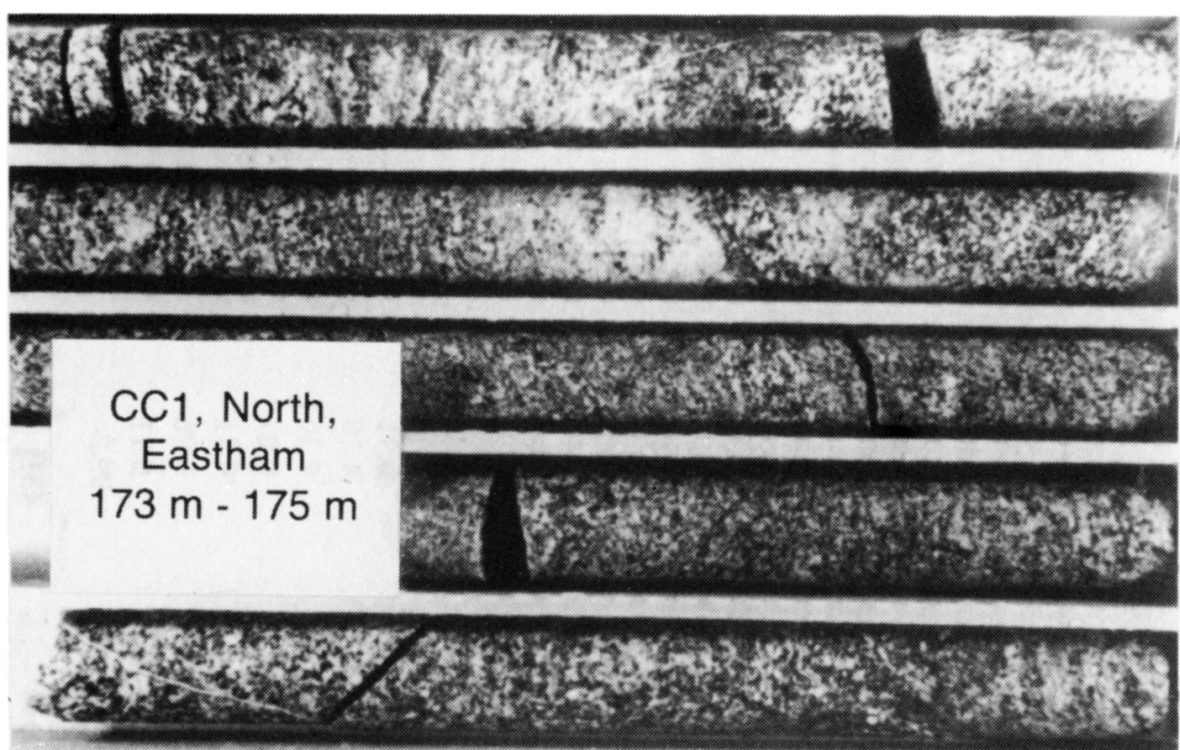

Fig. 3-3

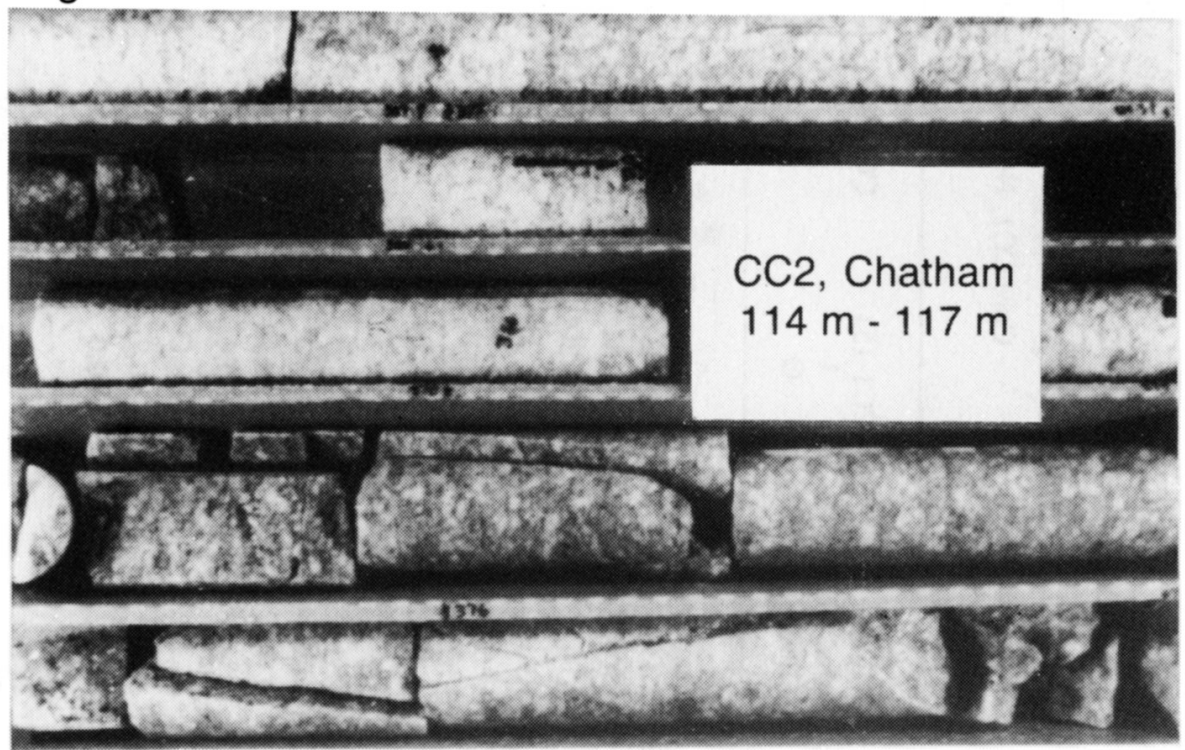

Fig. 3-4 


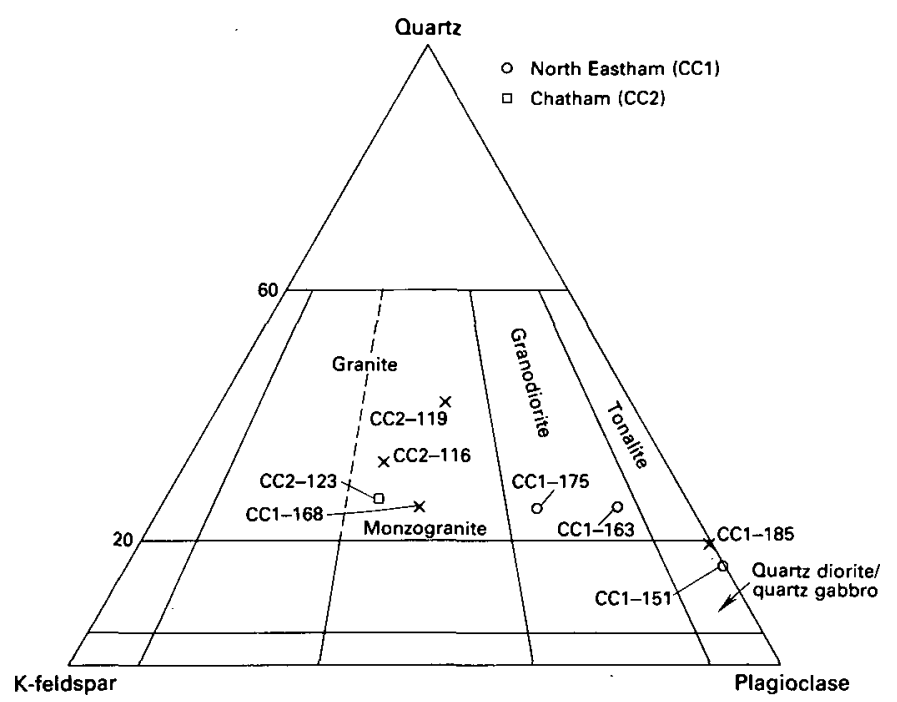

Fig. 4. Modal plot of quartz-K-feldspar-plagioclase from samples of cores $\mathrm{CC} 1$ and $\mathrm{CC} 2$ normalized to quartz+K-feldspar-plagioclase $=100 \%$. Chemically analyzed rocks (Table 2 ) are labelled 0 for $\mathrm{CC} 1$ and $\square$ for $\mathrm{CC} 2$, respectively; modally analyzed samples are shown by $x$.

abundance and also shows a significant negative Eu anomaly. These patterns are comparable to many calc-alkaline granites (e.g., Cullers and Graf, 1984), but may include more mafic rocks with calc-alkaline affinities. Taken together, the geochemical data suggest a somewhat different petrogenesis for the $\mathrm{CCl}$ samples as compared to that of CC2-123. The granite at Chatham Harbor is the most evolved of the four, consistent with other features described earlier.

\section{Geophysical Expression of Bedrock}

The two drill holes (CC1 and CC2; Fig. 2) straddle the Nauset anomaly, a linear, east-northeast trending feature marked by distinct gravity (Fig. 7-2) and magnetic anomalies (Fig. 7-1) that constitutes the boundary between the central and southern plutonic zones of Hutchinson et al. (1988). Aeromagnetic and gravity measurements of the drill sites were made to evaluate corresponding anomalies at depth (Leo and Phillips, 1989). The mineralogy of the crystalline cores generally reflects the observed patterns in regional magnetic susceptibility. The gabbroic phase of core $\mathrm{CC} 1$ contains about $5 \%$ magnetite, whereas the associated monzogranite phase contains 0.5 to $2 \%$ and the granite at Chatham Harbor about $0.5 \%$ (see Table 1 ). Hole CC1 coincides with a magnetic high subparallel to the Nauset anomaly, which is likely related to the relatively high magnetite content ( $5 \%)$ of the gabbroic phase. The felsic phase of $\mathrm{CC1}$, and also the granite of Chatham Harbor (CC2), are situated over magnetically featureless terrain which evidently defines the southern margin of the Nauset anomaly. The elongate gravity anomaly associated with the granite at Chatham Harbor (Fig. 7-1) and the negative anomaly trending eastward from Chatham suggests that the
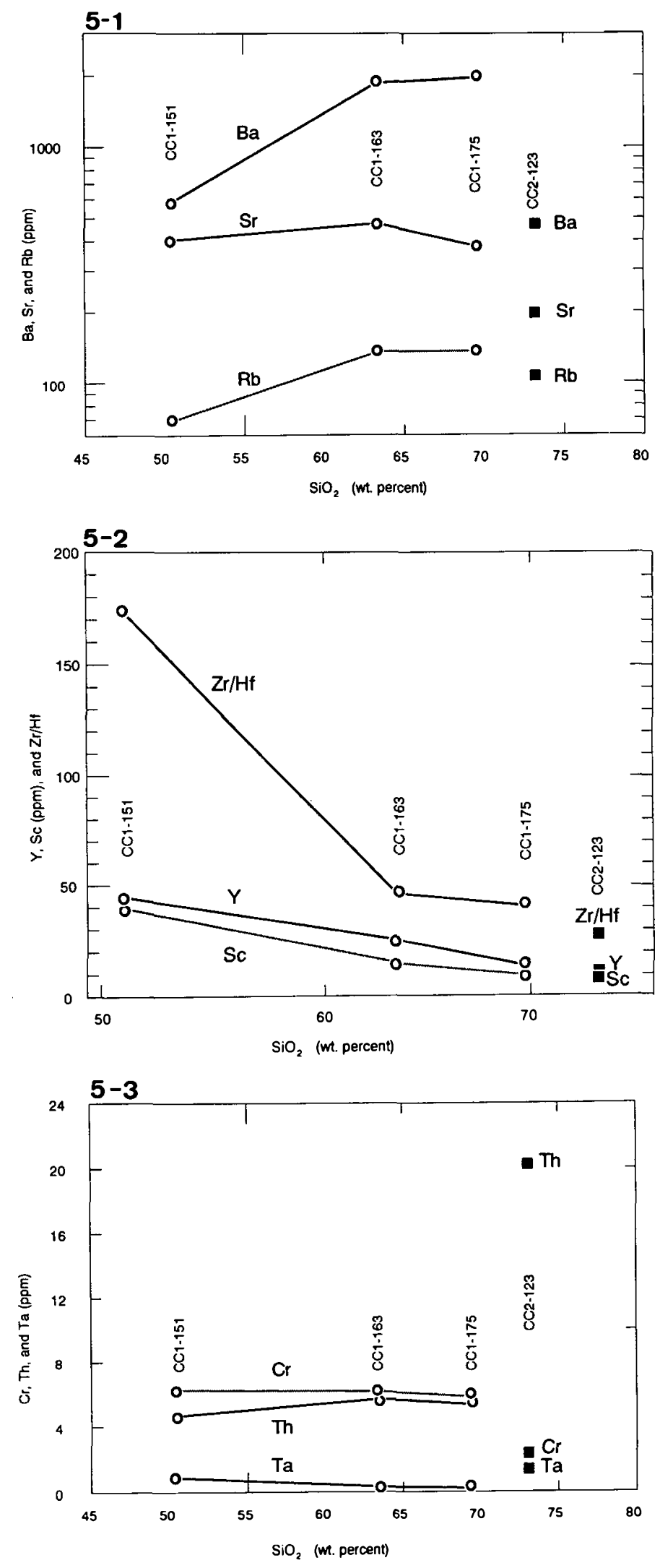

Fig. 5. Harker plot for $\mathrm{Ba}, \mathrm{Sr}$, and $\mathrm{Rb}$ abundances (Fig. 5-1), Y, Sc, and $\mathrm{Zr} / \mathrm{Hf}$ (Fig. 5-2), and $\mathrm{Cr}, \mathrm{Th}$, and $\mathrm{Ta}$ (Fig. 5-3) in $\mathrm{CCl}$ (North Eastham) and CC2 (Chatham Harbor) cores. 


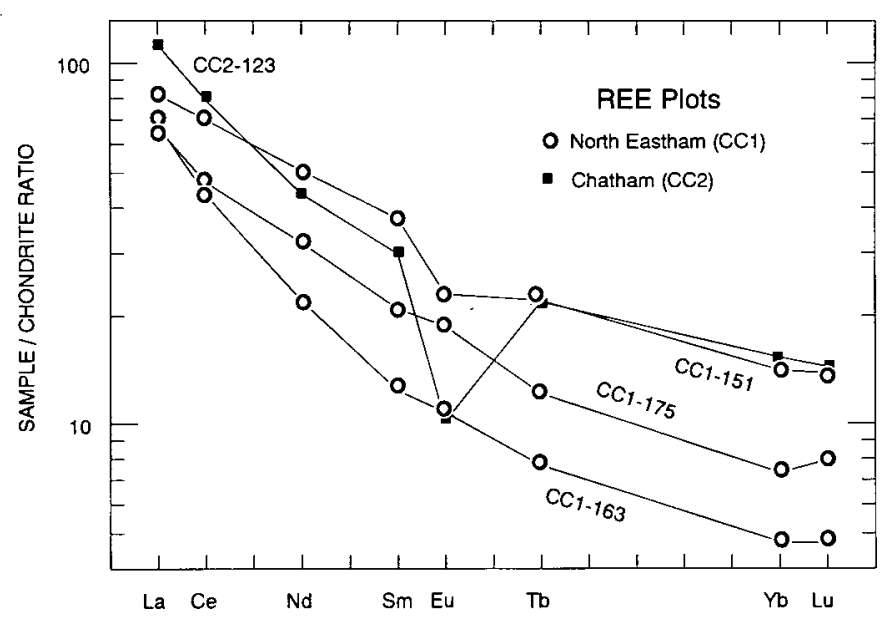

Fig. 6. REE plots for analyzed samples of North Eastham (CC1) and Chatham Harbor (CC2) granite.

granite at Chatham Harbor may be the western end of a larger granite body.

\section{Geochronology}

Zircon was recovered only from sample CC2-132. Mineral concentrates were prepared using standard Wilfley table, heavy liquid and magnetic separation techniques. Individual mineral fractions for $\mathrm{U}-\mathrm{Pb}$ analysis were separated and purified based on grain size, morphology and magnetic susceptibility, and hand-picked to $100 \%$ purity. Four zircon fractions were analyzed at Dartmouth College, and three additional fractions were subsequently analyzed at the Geochronology Laboratory of the Geological Survey of Canada (GSC) in Ottawa.

$\mathrm{U}-\mathrm{Pb}$ analytical techniques employed at Dartmouth College were modified slightly from those of Mattinsen (1987). Data reduction was done using the PBDAT program (v. 1.06) of Ludwig (1990). Errors were estimated based on reproducibility of standards. $\mathrm{U}$ and $\mathrm{Pb}$ procedural blanks averaged 0.030 and $0.120 \mathrm{ng}$, respectively. Analytical procedures used at the Geological Survey of Canada are described in detail by Parrish et al. (1987). Concentration data were obtained using a ${ }^{233 \cdot 235} \mathrm{U} /{ }^{205} \mathrm{~Pb}$ spike. Measured blank levels were 0.006 to $0.015 \mathrm{ng}$ for $\mathrm{Pb}$, and $<0.001 \mathrm{ng}$ for $\mathrm{U}$. Isotopic measurements were made on a Finnegan MAT 261 solid source mass spectrometer operated in static mode. Errors were propagated numerically using the method described by Roddick (1987).

Both the Dartmouth and GSC analyses were corrected for initial common $\mathrm{Pb}$ using the $\mathrm{Pb}$ isotopic composition measured on coexisting potassium feldspar. Discordia line fitting and calculation of upper and lower concordia intercept ages and associated errors employed the regression model of Davis (1982). All errors are quoted at the $2 \delta$ level.

Fig. 7. Aeromagnetic map (Fig. 7-1) and gravity map (Fig. 7-2) of Cape Cod region.
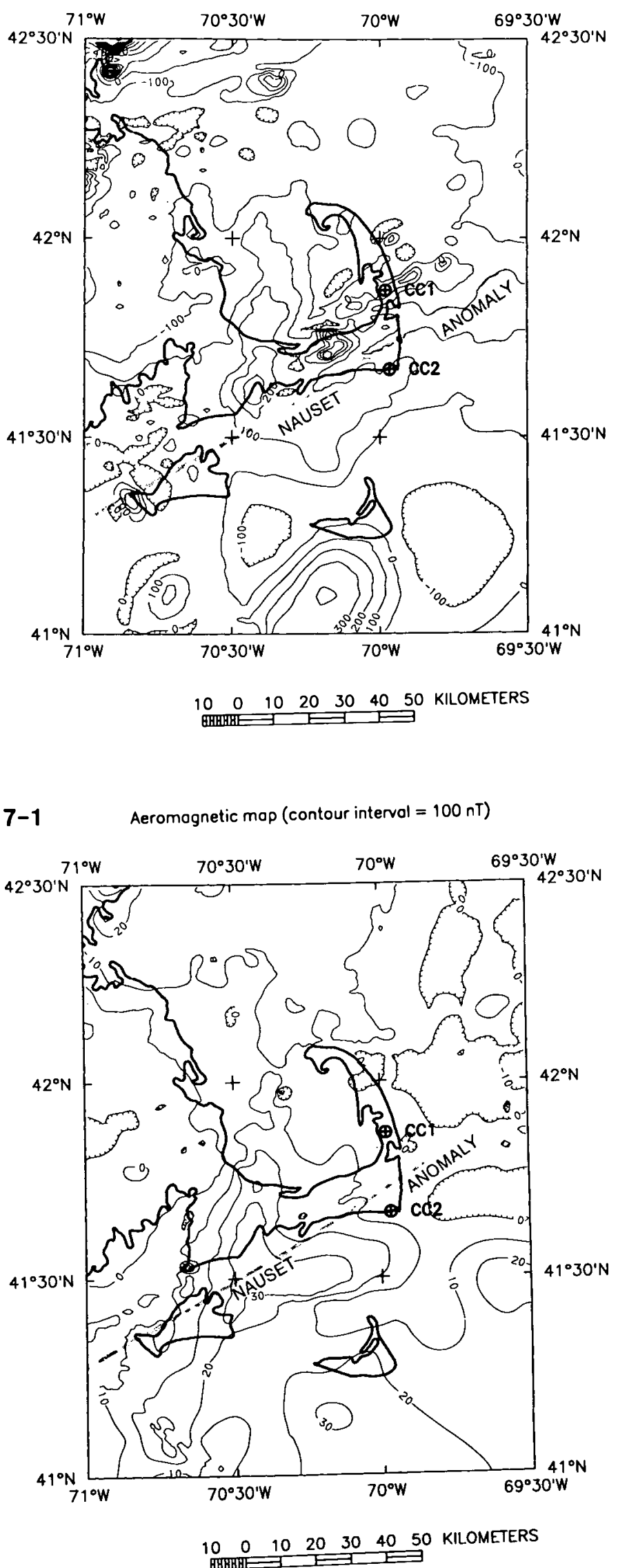

7-2 Gravity map (contour interval $=10 \mathrm{mGal}$ ) 
Table 3. U-Pb data for granite (CC2) at Chatham Harbor, southeastern Cape Cod.

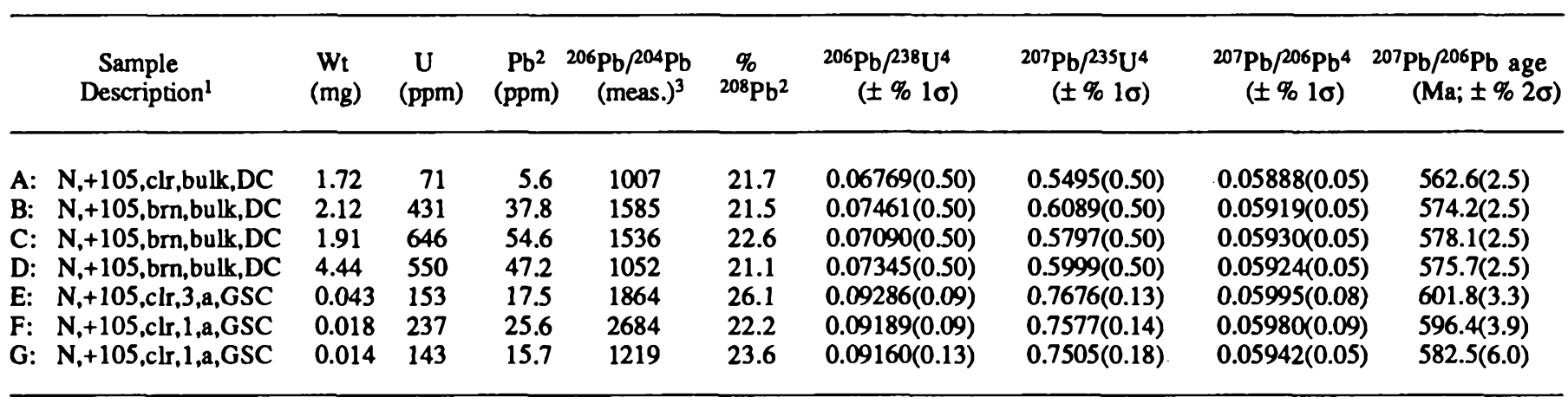

${ }^{1}$ clr, clear, bm, brown; $+105,>105 \mu$ diameter, DC, Dartmouth analyses; GSC, Geological Survey of Canada; a, abraded; 3,1, number of grains analysed

${ }_{\text {radiogenic }} \mathrm{Pb}$; corrected for blank, spike, and initial common $\mathrm{Pb}$ (measured on coexisting feldspar) at ${ }^{208} \mathrm{~Pb} /{ }^{204} \mathrm{~Pb}=38.65,{ }^{207} \mathrm{~Pb} /{ }^{204} \mathrm{~Pb}=15.65,{ }^{206} \mathrm{~Pb} / 204 \mathrm{~Pb}$ $=18.91$

3 corrected for spike and fractionation

${ }^{4}$ correcied for blank $\mathrm{Pb}$ and $\mathrm{U}$, and common $\mathrm{Pb}$

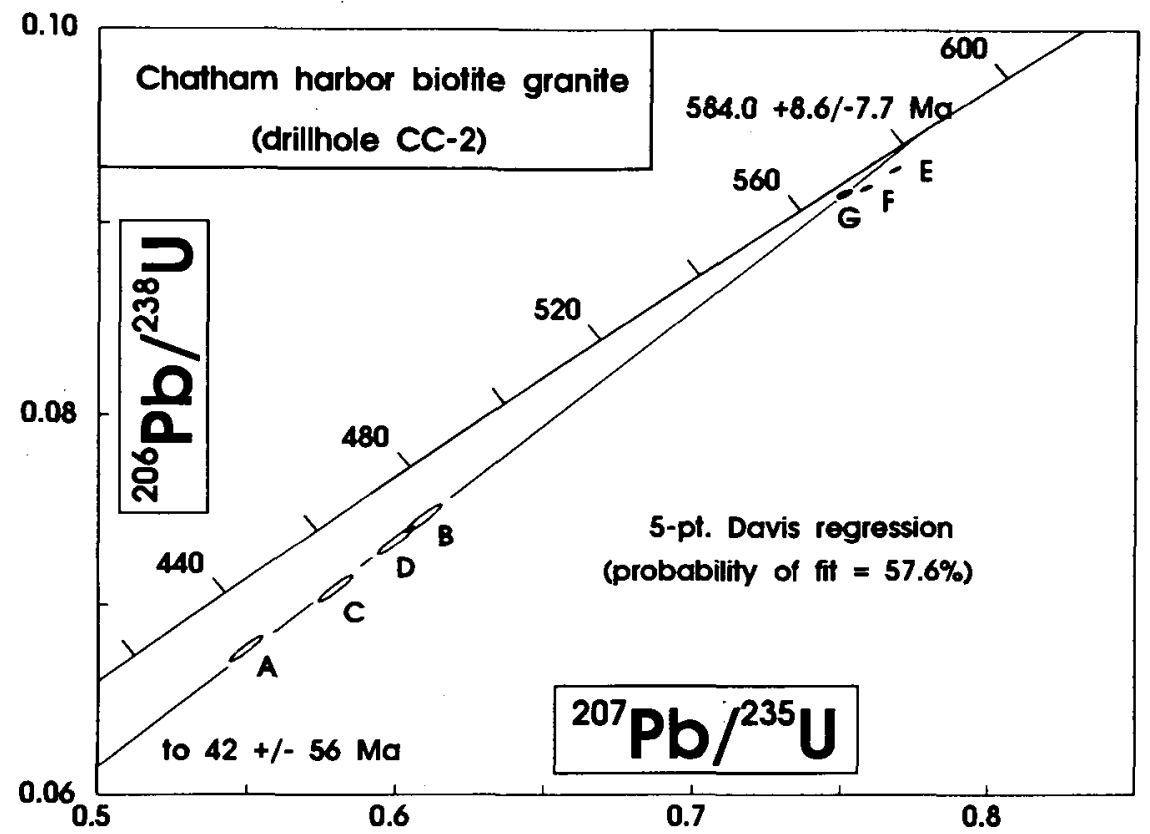

Fig. 8. Concordia plot for granite at Chatham Harbor (sample CC2).

Zircons recovered from the sample consist of pale to dark brown, strongly fractured, stubby, euhedral prisms with abundant clear, bubble- and rod-shaped inclusions. Vague- to well-developed igneous zoning is visible in most of the grains, but no inherited cores were observed.

Analytical data for the seven fractions (Table 3) are shown on a conventional U-Pb concordia plot in Figure 8. The original four analyses (open ellipses A-D; see Fig. 8) were of bulk unabraded zircon fractions. The analyses define a short linear array, but are all strongly discordant (24-31\%). Two single grains and a fraction consisting of three grains were subsequently selected from the best quality zircons remaining, and strongly abraded. The three new analyses (solid ellipses E-G; see Fig. 8) plot much closer to concordia (3-5\% discordant), but display considerable scatter that we interpret to reflect the presence of a minor inherited zircon component. Data for the three abraded fractions do not define a sufficiently long array to give meaningful upper and lower intercept ages. The ${ }^{207} \mathrm{~Pb} /{ }^{06} \mathrm{~Pb}$ age of the most concordant fraction ( $G ; 582.5 \pm 6.0 \mathrm{Ma})$ represents a maximum possible age for the sample. A regression line through this analysis and the four more discordant analyses (A-D) gives calculated upper and lower intercept ages of $584.0+8.6 /-7.7 \mathrm{Ma}$ and $42 \pm 56 \mathrm{Ma}$, respectively, with a probability of fit of $57.6 \%$. The lower intercept age indicates that the $\mathrm{Pb}$-loss that affected this unit was mainly relatively recent. We consider the upper intercept age to be the best estimate for the crystallization age of the rock. The data preclude the calculation of an average age for the inherited zircon component. 


\section{Discussion}

Recent seismic reflection profiling in the Gulf of Maine by Hutchinson et al. (1988) has identified the major tectonic features in this region. The exact location of the Avalon-Meguma boundary in the Gulf of Maine is a matter of some debate. This boundary is well defined in northern Nova Scotia (see summary by Keen et al., 1991), from where it turns southeastward into the Gulf of Maine (Fig. 1). Keen et al. (1991) argued that the Avalon-Meguma boundary is marked by the previously described Nauset anomaly (Figs. 1, 2), an east-northeast-trending, relatively low amplitude magnetic lineament. Hutchinson et al. (1988) concluded that much of the central and southern Gulf of Maine is underlain by plutonic rocks which they divided into two zones, based on minor differences in magnetic and seismic signatures. The Nauset anomaly coincides with the boundary between their central and southern plutonic zones. Both of these zones were considered by Hutchinson $e t$ al. (1988) to be part of the Avalon terrane, with the AvalonMeguma boundary lying at least $30 \mathrm{~km}$ farther southeast of the Nauset anomaly. As discussed above, the two drillholes from which we obtained our samples for this study are located on opposite sides of the Nauset anomaly (Fig. 2). Petrographic data presented here support the existence of the anomaly. The $584 \mathrm{Ma} \mathrm{U}-\mathrm{Pb}$ zircon age for the granite at Chatham Harbor on the southern side of the Nauset anomaly is in good agreement with U-Pb zircon ages reported for volcanic and plutonic units in the Avalon terrane farther north (Fig. 1). Although some plutons in the Meguma terrane in Nova Scotia contain inherited zircon cores in the range of 650 to $560 \mathrm{Ma}$ (Krogh and Keppie, 1988), only Silurian and Devonian crystallization ages have been obtained thus far for plutons in this terrane. Thus our age data indicate that the part of Cape Cod southeast of the Nauset anomaly is part of the Avalon terrane, as suggested by Hutchinson et al. (1988).

Although the plutonic rocks intersected by the two drill holes show a generally calc-alkaline character, petrographic and geochemical studies suggest that the granite at Chatham Harbor (CC2) is distinct from the more heterogeneous plutonic unit(s) intersected by hole $\mathrm{CCl}$, and apparently represents a distinct igneous suite. Available data do not permit determination of the relative age of the plutonic rocks intersected by the two drill holes.

\section{Acknowledgements}

Leo wishes to acknowledge several U.S. Geological Survey colleagues as follows: Stephen Schindler (computer graphics), Stephen Snyder (geophysical maps), Lewis Thompson (photographic work), and Byron Stone for planning and initiation of the drilling project. We thank the staff of the Geochronology Laboratory at the Geological Survey of Canada (Ottawa) for assistance in producing some of the $\mathrm{U}-\mathrm{Pb}$ analytical results. The manuscript benefited from reviews by M.L. Bevier, D. Nance and J.C. Hepburn.
Barr, S.M., Dunning, G.R., Raeside, R.P., and Jamieson, R.A. 1990. Contrasting U-Pb ages of plutons in the Bras d'Or and Mira terranes of Cape Breton Island, Nova Scotia. Canadian Journal of Earth Sciences, 27, pp. 1200-1208.

Bevier, M.L. and BARR, S.M. 1989. U-Pb age constraints on the stratigraphy and tectonic history of the Avalon Terrane, New Brunswick, Canada. Journal of Geology, 98, pp. 53-63.

Bevier, M.L., White, C.E., and Barr, S.M. 1990. Late Precambrian U-Pb ages for the Brookville Gneiss, southern New Brunswick. Journal of Geology, 98, pp. 955-965.

Cullers, R.L. and Grap, J.L. 1984. Chapter 8, Rare-earth elements in igneous rocks of the continental crust, Intermediate and silicic rocks--ore petrogenesis. In Rare earth element geochemistry, Development in geochemistry 2. Edited by P. Henderson. Elsevier, pp. 275-308.

Dallmeyer, R.D., Doig, R., Nance, R.D., and Murphy, J.B. 1990. ${ }^{40} \mathrm{Ar}{ }^{\circ 9} \mathrm{Ar}$ and $\mathrm{U}-\mathrm{Pb}$ mineral ages from the Brookville Gneiss: implications for terrane analysis and evolution of Avalonian "basement" in southern New Brunswick. Atlantic Geology, 26, pp. 247-257.

DA VIS, D.W. 1982. Optimum linear regression and error estimation applied to U-Pb data. Canadian Journal of Earth Sciences, 19, pp. 2141-1249.

Doig, R., Murphy, J.B., Nance, R.D., and Stokes, T. 1991. Review of the geochronology of the Cobequid Highlands, Avalon composite terrane, Nova Scotia. In Current Research, Part D, Geological Survey of Canada, Paper 91-1D.

Hutchinson, D.R., Klitgord, K.D., Lee, M.W., and Trehu, A.M. 1988. U.S. Geological Survey deep seismic reflection profile across the Gulf of Maine. Geological Society of America Bulletin, 100, pp. 172-184.

Keen, C.E., Kay, W.A., KepPie, D., Marillier, F., Pe-Piper, G., and WALDRON, J.F.W. 1991. Deep seismic reflection data from the Bay of Fundy and Gulf of Maine: tectonic implications for the northern Appalachians. Canadian Journal of Earth Science, 28, pp. 1096-1111.

Keppie, J.D., Dallmeyer, R.D., and Murphy, J.B. 1990. Tectonic implications of ${ }^{40} \mathrm{Ar} /{ }^{39} \mathrm{Ar}$ hornblende ages from late Proterozoic-Cambrian plutons in the Avalon Composite Terrane, Nova Scotia, Canada. Geological Society of America Bulletin, 102, pp. 516-528.

KroGh, T.E. and KePPIE, J.D. 1988. U.Pb ages of single zircon cores imply a Pan African source for two Meguma granites. Geological Association of Canada, Program with Abstracts, 13, p. A69.

Leo, G.W. and PhiLlips, J.D. 1989. New drill cores in crystalline bedrock on southeastern Cape Cod, Massachusetts (abstract). Geological Society of America, Abstracts with Programs, 21 (2), p. 28.

Leo, G.W., Barreiro, B., and Mortensen, J.K. 1991. A latest Proterozoic $\mathrm{U}-\mathrm{Pb}$ age for plutonic basement rocks in southeastern Cape Cod, Massachusetts. Geological Society of America, Abstracts with Programs, 23 (1), p. 58.

LuDwiG, K.R. 1990. PBDAT (version 1.06): a computer program for IBM-PC compatibles for processing raw $\mathrm{Pb}-\mathrm{U}-\mathrm{Th}$ isotopic data. U.S. Geological Survey, Open-File Report 88542.

MATTinSen, J.M. 1987. U-Pb ages of zircons: a basic examination of error propogation. Chemical Geology, 66, pp. 151-162.

Parrish, R., Roddick, J.C., Loveridge, W.D., and Sullivan, R.W. 1987. Uranium-lead analytical techniques at the geochronology laboratory: Geological Survey of Canada. In 
Radiogenic Age and Isotopic Studies: Report 1. Geological Survey of Canada, Paper 87-2, pp. 3-7.

RoDDICK, J.C. 1987. Generalized numerical error analysis with application to geochronology and thermodynamics. Geochem. Cosmochim. Acta, 51, pp. 2129-2135.

Sanoster, A.L., Hunt, P.A., and Mortensen, J.K. 1990. U-Pb geochronology of the Lime Hill gneissic complex, Cape Breton Island, Nova Scotia. Atlantic Geology, 26, pp. 229236.

Wones, D.R. and Goldsmith, R. 1991. Intrusive Rocks of Eastern Massachusetts. In Chapter I, I1-I61, The Bedrock Geol- ogy of Massachusetts. Edited by N.L. Hatch, Jr. U.S. Geological Survey, Professional Paper 1366I-J.

Zartman, R.E. and Marvin, R.F. 1991. Radiometric ages of rocks in Massachusetts. In The Bedrock Geology of Massachusetts. Edited by N.L. Hatch, Jr. U.S. Geological Survey, Professional Paper 1366-E-J, pp. J1-J19.

Zen, E-An (editor) and Goldsmith, R., Ratcliffe, N.M., Robinson, P., and Stanley, R.S. (compilers). 1983. Bedrock geologic map of Massachusetts: Reston, Virginia. U.S. Geological Survey, 3 sheets, scale 1:250,000. 